\title{
The Utilization of Cassava and Sorghum Flours as A Staple Food in Indonesia
}

\author{
Setiyo Gunawan1, Nur Istianah2, Hakun Wirawasista Aparamarta1, Raden Darmawan1, Lailatul \\ Qadariyah1, and Kuswandi1 \\ 1Department of Chemical Engineering, Institut Teknologi Sepuluh Nopember (ITS), Surabaya 60111 Indonesia \\ 2Agricultural Products Technology, Brawijaya University, Malang 65145, Indonesia \\ gunawan@chem-eng.its.ac.id
}

\begin{abstract}
Abstrak
Indonesia has high a demand level of wheat flour for both the industrial and households sectors, such as bread industry. Wheat flour is the dominant composition of bread, however it is the source of gluten which may promote celiac disease (CD). The lifetime obedience to the gluten-free diet is the only treatment for this disease. The finding of a new material in order to obtain gluten-free product is an important topic. Furthermore, Indonesia is a tropical region that is rich in natural resources, such as cassava (Manihot esculenta) and Sorghum (Sorghum-bicolor (L) Moech). Fermentation was used to improve nutritional content of sorghum flour and cassava flour, resulting modified cassava flour (mocaf) and modified sorghum flour (mosof), respectively. A strategy for utilization of cassava in production of mocaf was demonstrated. Mocaf flour can be produced by fermentation use L. plantarum, S. cereviseae, and R. oryzae that are cheap and non pathogenic to increase the levels of protein and decrease the levels of cyanide acid in the mocaf flour. This work has also shown that lactid acid is produced as by-product during the fermentation.
\end{abstract}

Keyword: cassava, celiac disease, fermentation, sorghum, wheat

\section{INTRODUCTION}

Recently, bread is one of common food that are also become a stuff food in Indonesia. Ingredients of bread are commonly wheat flour, water, salt, yeast, sugar, shortening (margarine), egg, and milk. Wheat flour is the dominant composition, while it is the source of gluten. Moreover, gluten content of cake or baking product promotes celiac disease. Celiac disease is a syndrome characterized by damage of the small intestinal mucosa caused by the gliadin fraction of wheat gluten and similar alcohol soluble proteins (prolamins) of barley and rye in genetically susceptible subjects.

The presence of gluten in foods, leads to self-perpetuating mucosal damage, whereas elimination of gluten results in full mucosal recovery [1]. The only treatment is the lifelong adherence to the gluten-free diet. When gluten is removed from the diet, the small intestine will start to heal and overall health improves. Therefore, finding alternative gluten free flour sources are becoming one of the hot research topics, such as cassava (Manihot esculenta) and sorghum (Sorghum bicolor $L$. Moench).

Within the abundance in Indonesia, cassava is mostly connoted as "tuppenny goods". Cassava is often considered as low quality raw materials, such as low in protein, minerals and vitamins contents. Conversion of sorghum seeds into flour as food is rarely founded. Most of the people use sorghum seeds as animal feed only.

The objective of this study was to modify cassava and sorghum flour by fermentation in order to get the flour with higher nutritional value and safe for consumption. In this study, cassava tubers and grain sorghum were fermented to increase the protein content, as well as improving the quality of bread.

\section{LITERATURE STUDY}

Cassava is one of local carbohydrate source from Indonesia which is occupying the third position after rice and corn as a staple food as can be seen in Figure 1. The cassava is an important component in the diets of more than 800 million people around the world. It is kind of tropic and sub-tropic plant. Cassava needs at least 8 months in the summer for producing ripe cassava. Cassava is able to grow in less-nutrition soil. In a dry land, cassava will shed its leaves to keep it damp and produce new leaves in the rainy season. Otherwise, cassava can not survive in cold weather but it can grow very well in the area with $\mathrm{pH} 4-8$. The quality of Indonesia's cassava should be developed into food commodities and alternetive energy as subtitution of fuel oil because it will give added value for cassava farmer in Indonesia. 


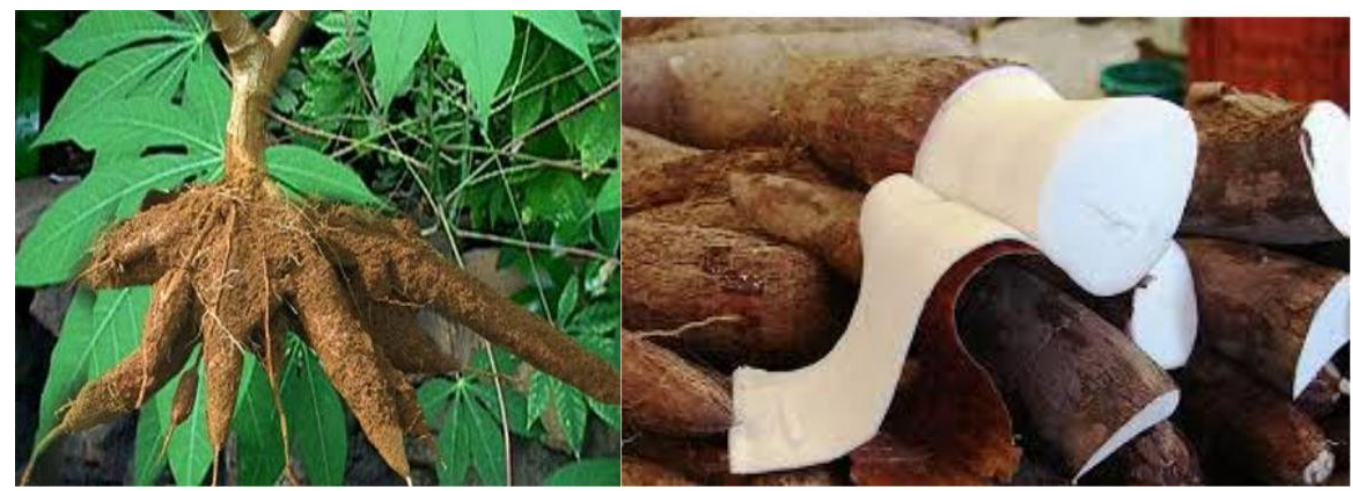

Figure 1 Cassava (Manihot esculenta)

Sorghum has good potentials as a nutritionally improved food as can be seen in Figure 2. Sorghum flour can replace or combine to wheat flour to get gluten-free product. Sedej (2011) reported that crackers made from buckwheat (sorghum) flours can increase supply of gluten-free products on the market and may be regarded as health promoting functional foods, especially for celiac disease patients. Sorghum dried starch had a composition of $10.73 \%$ moisture, $0.30 \%$ ash, $1.06 \%$ protein and $1.07 \%$ fat. Amylose content was $21.08 \%$ and the average granule size and $\mathrm{pH}$ were $18.59 \mu \mathrm{m}$ and 5.45 , respectively (Aviara, 2010). Elkhalifa et al. (2004) noted that fermented sorghum flour had a better properties than nonfermented sorghum, e.g. the higher solubility of its starch, and lower water binding capacity. They reported that sorghum flour was fermented by the traditional Sudanese method of fermentation in $37^{\circ} \mathrm{C}$ for $24 \mathrm{~h}$. After a distinct incubation period, the samples were dried in a hot air oven (Heraeus UT 5042, Germany) at $60^{\circ} \mathrm{C}$ for $16 \mathrm{~h}$. Dried samples were ground to pass a $0.4 \mathrm{~mm}$ screen and stored in polyethylene bags at $4{ }^{\circ} \mathrm{C}$ prior to analysis.
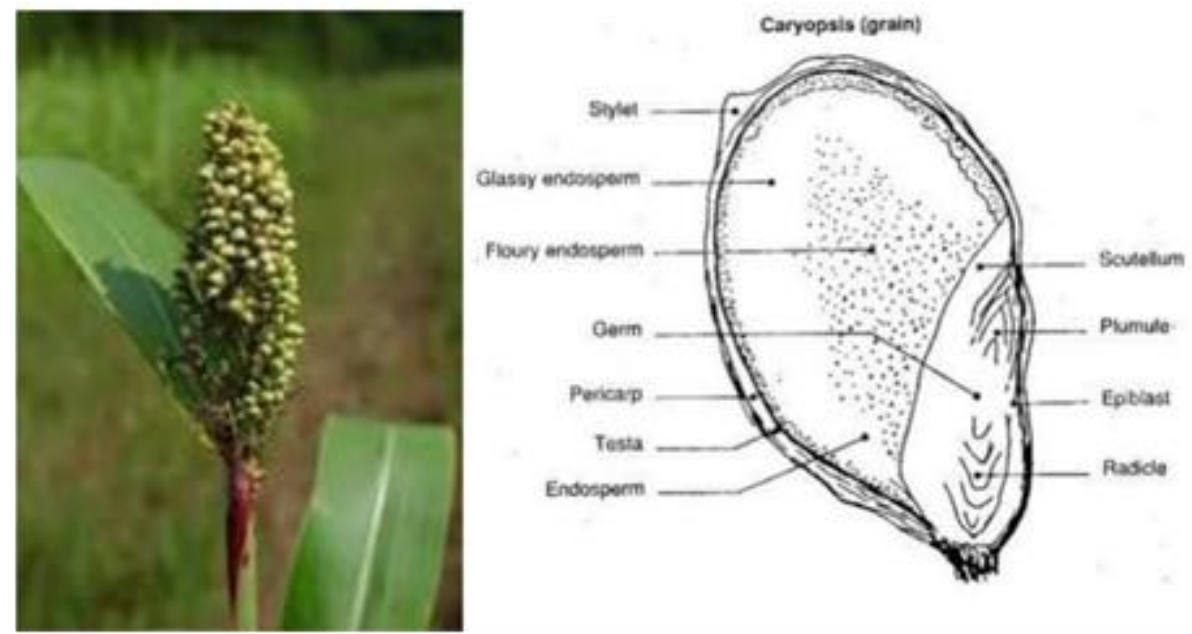

Figure 2 Sorghum (Sorghum bicolor L.Moench)

\section{RESEARCH METHODOLOGY}

\subsection{Materials}

White cassava tubers were purchased from local markets in Surabaya (Indonesia) with a diameter and length of 2-3 cm and 50-80 cm, respectively. Sorghum seeds were obtained from Pemalang, Indonesia. All solvents, microbes and reagents were obtained from commercial sources.

\subsection{Cassava fermentation}

Cassava fermentation process was carried out by submerged fermentation method as described by previous work [2].

\subsection{Proximate composition}

Ash, fiber, protein, and nitrogen free extract contents of dried fresh and fermented cassavas were determined by [3]. Lipid content of dried fresh and fermented cassavas was analyzed as described by previous work [4]

Fixed carbon was measured by ASTM D 3172 (1986). Moisture and mineral contents of dried fresh and fermented cassavas were analyzed using a Halogen moisture analyzer and Inductively Coupled Plasma Optical Emission Spectrometry (ICPEOS), respectively.

\section{4. $\mathrm{pH}$ analysis}

The $\mathrm{pH}$ of filtrate obtained from fermentation was determined by $\mathrm{pH}$ meter as described by previous work [2].

\subsection{Lactic acid analysis}

The lactic acid content of filtrate obtained from fermentation was determined by total titrable acidity ([5].

\subsection{Analysis of $\mathrm{HCN}$ content}


The cyanide acid content of washed fresh and fermented cassavas was determined by[6].

3.7. Analysis of starch content

Acid metho[3] was used to determine starch content of washed and fermented cassava.

\section{RESULTS AND DISCUSSION}

Cassava production has increased consistenly in Indonesia. Cassava contains toxic substances, including of cyanide acid. Another, it has low content in protein, minerals, and vitamins. Moreover, most of the people use sorghum seeds as animal feed only. Therefore, a special proccessing is important prior to consumption. In this study, modified cassava flour (mocaf) and modified sorghum flour (mosof) production without any additional nutrients at different microorganisms and fermentation times, were investigated.

There are several different methodologies for fermentation process of cassava (liquid, solid state, submerged, culture and spontaneous fermentations), different microorganisms (yeast, fungi and bacteria) and different additional nutrients (with and without nutrients) for enhancing detoxification and improving the quality of cassava flour [7].

Proximate and minerals composition of fermenting flour were also presented [2]. It was found that at the microbial to cassava mass ratio of $1 \%$ for fermentation time of $120 \mathrm{~h}$, L. plantarum, S. cereviseae, and R. oryzae on cassava can increase the levels of protein from $1.92 \%$ to $8.58 \%, 2.29 \%$, and $4.72 \%$, respectively. In addition, it can reduce starch content after fermentation in a number of $55.40 \%, 71.03 \%$, and $48.20 \%$, respectively. Moreover, the levels of cyanide acid was decreased from $17.5 \mathrm{mg} / \mathrm{kg}$ to $1.8,3.28$, and $3.17 \mathrm{mg} / \mathrm{kg}$, respectively.

Mocaf and mosof can be produced by fermentation use L. plantarum, S. cereviseae, and R. oryzae that are cheap and non pathogenic to increase the levels of protein and decrease the levels of cyanide acid in the mocaf flour. It was found that $L$. plantarum was more efficient than $S$. cereviseae, and $R$. oryzae. This work has also shown that lactid acid is produced as by-product during the fermentation.

Moreover, L. plantarum was used to improve the nutritional values and bread properties sorghum flour. The optimization of the fermentation was conducted at the mix of dry baker yeasts and pure L. plantarum with $30 \%$ sorghum flour concentration $(\mathrm{w} / \mathrm{w})$ for $24 \mathrm{~h}$. The fermented sorghum flour has a lower content of moisture $(3.3 \% \mathrm{w} / \mathrm{w})$ and fat $(2.8 \%$ $\mathrm{w} / \mathrm{w})$, and also a higher content of protein $(23.4 \% \mathrm{w} / \mathrm{w})$, ash $(9.52 \% \mathrm{w} / \mathrm{w})$, and total phenolic contents $(1.8 \% \mathrm{w} / \mathrm{w})$. Another, It was also found that amylose content of fermented sorghum flour decrease by $64 \%$. Furthermore, it was shown that fermented sorghum flour has ability to increase volume expand of bread dough, to decrease bread crumb hardness and to produce darker bread color. Moreover, its nutritional value was higher than those of bread with $100 \%$ wheat flour and bread with $30 \%$ non-fermented sorghum flour. Fermentation of sorghum flour by mix of dry baker's yeast and L. Plantarum at the optimum condition provided higher nutritional value than non-fermented sorghum flour and wheat flour. And more, it has influence to the rheological properties of flour. Whereas, its application increased volume expand, decreased bread crumb hardness and produced darker bread color. Since the higher protein content of fermented sorghum flour has some advantages to the bread,

\section{CONCLUSION}

In Indonesia, mocaf and mosof have good prospect because of the cassava and sorghum availability and low cost production. A strategy for utilization of cassava and sorghum in production of mocaf and mosof were demonstrated. Mocaf and mosof are expected to be the wheat flour alternative substitutes. It is necessary to study the characterization of the amino acids in the fermented flour in the future.

\section{REFERENCES}

[1] A. and C. C. Fasano, "Current Approaches to Diagnosis and Treatment of Celiac Disease: An Evolving Spectrum," Gastroenterology, vol. 120, pp. 636-651, 2001.

[2] D. Gunawan, S., Widjaja, T., Zullaikah, S., Ernawati, L., Istianah, N., Aparamarta, H.W. and Prasetyoko, "Effect of fermenting cassava with Lactobacillus plantarum, Saccharomyces cereviseae, and Rhizopus oryzae on the chemical composition of their flour," Int. Food Res. J., vol. 22, pp. 1280-1287, 2015.

[3] AOAC, Official methods of analysis of AOAC International. Gaithersburg: Association of Analytical Communities, 2003.

[4] H. Gunawan, S., Darmawan, R., Nanda, M., Setiawan, A.D. and Fansuri, "Proximate composition of Xylocarpus moluccensis seeds and their oils," Int. J. Ind. Crop. Prod., vol. 41, pp. 107-112, 2013.

[5] G. Niro, Analytical methods A titratable acidity. Denmar: GEA Process Engineeering A/S, 2006.

[6] S. Standard, Modified cassava flour. SNI 7622. Jakarta: National Standardization Agency of Indonesia, 2011.

[7] F. S. and I. D. Gunawan, Setiyo, Zikrina Istighfarah, Hakun Wirawasista Aparamarta, Utilization of modified cassava flour and its by products. In Handbook on Cassava_Production, Potential Uses and Recent Advances. New York: Nova Publisher, 2016. 